Прегледни чланак

Bojan V. Božović, Ph.D., Judge

Basic Court in Novi Sad

bojan.bozovic@ns.os.sud.rs

\title{
THE VERY BEGINNING OF THE SERBIAN SOCIAL SECURITY LAW IN THE SAINT SAVA'S NOMOCANON
}

\begin{abstract}
Despite the fact that freedom of labor as an assumption of social public policy has emerged only in capitalist society, the article indicates that certain initial elements- seeds of social security law can be recognized even in ancient and middle ages. In accordance with that context, the subject of this research is the largest middle age codex in Serbia, the Saint Sava's Nomocanon, its provisions based on the idea of social justice, provisions aimed at fulfillment of social requirements and used as a response to social risks and social cases, as well as institutionalization of special protection of women, children and family. That said brings us to the conclusion that the observed provisions of the Saint Sava's Nomocanon, the very ones that promote Christian doctrine of social justice and that contain a line of ethical requirements which influence the process of moralization of social relations, are essentially identical with the idea of social justice of the modern state of welfare within the European social model, as well as with the emancipation role of social security law and that the legal institutions of the Saint Sava's Nomocanon are the very beginning of the Serbian social security law.
\end{abstract}

Keywords: medieval Serbia, Saint Sava, nomocanon, social security law.

Individual freedoms, primarily the freedom to work, are preconditions for the emergence of labor and social security law, once these preconditions are fulfilled the very emergence of labor and social security law implies a particular interventionism by public bodies in labor and social security relations in favorem laboratoris, i.e., the establishment of a social public order. ${ }^{1}$ Although individual freedoms are the products of a capitalist society, certain initial elements - the seeds

\footnotetext{
${ }^{1}$ Бранко Лубарда, Радно йраво - расйрава о достиојанстиву на раду и соиијалном дијалогу, Правни факултет Универзитета у Београду, Београд 2012, 156-159.
} 
of labor and social security law, can be identified in the ancient and middle ages, ${ }^{2}$ where it should be emphasized that social security law is a branch of law which encompasses legal norms, institutes, institutions and relations aimed at ensuring man's safe and dignified social position, from which follows that the reason for the existence of social security law lies in the social need of individuals and social groups, and society's interest in providing basic social security to all its members through the provision of social benefits ${ }^{3}$. It is also important to point out that human rights, as a complementary set of civil-political and socio-economic rights, are an expression of the unique need of society to provide people with a dignified life and work founded on the idea of justice, thus consequently social justice. ${ }^{4}$ Within this context, the subject of this paper will be the most extensive Serbian medieval codex, the Nomocanon of Saint Sava, ${ }^{5}$ which contains the seeds of social justice in the form of provisions based on the idea of social justice, norms aimed at meeting social needs, and provisions that address social risks and social cases. Of note is that the basis of the Nomocanon is the legislation of the church in Byzantium, and Byzantine civil law, which was adapted by the authors, in a diverse and loose form, to fit the socio-economic relations existing in the Serbian medieval state through expansion, removal and modification of adopted norms, as well as the introduction of new authentic provisions. ${ }^{6}$

\section{THE IDEA OF SOCIAL JUSTICE IN THE NOMOCANON}

At the very beginning, in the fourth introductory chapter of the St. Sava's Nomocanon, ideas of equality and solidarity are promoted, and oppression is prohibition, which in itself is a clear departure from slavery ${ }^{7}$ which was, at the time

${ }^{2}$ Ibid.

${ }^{3}$ Сенад Јашаревић, Соиијално йраво, Правни факултет Универзитета у Новом Саду, Нови Сад 2010, 5-6; Боривоје Шундерић, Социјално йраво, Правни факултет Универзитета у Београду, Београд 2009, 143-166.

4 Предраг Јовановић, „Радноправне димензије социјално-економских права у европском и нашем праву“, Зборник радова Правног̄ факулиеиейа у Новом Саду 2/2006, 343357; Предраг Јовановић, „Нормативна изградња људских и социјално-економских права“, Зборник радова Правног̄ факулӣеӣа у Новом Саду 3/2010, 103-115.

${ }^{5}$ Nomocanon is a literary Serbian word and the original name of the St. Sava's Nomocanon, unfoundedly called Krmčija in literature, due to the influence of Russian transcriptions of the St. Sava's Nomocanon;

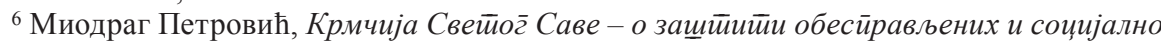
угірожених, Београд 1990, 4 и 75.

7 „Онај ко Бога Оцем назива, да буде праведан и да живи тако како се не би показао недостојним таквог сродства. А саветује и то да браћа иду на заједничку молитву, јер не рече Оче мој, већ Оче наш, узаконивши да молитве приносимо за опште црквено тело те никако да неко брине само о себи него увек и о ближњем, и да нико ни у чему не буде бољи 
of the creation of the first Serbian codex, still a social reality. ${ }^{8}$ In addition, many other diversified provisions disbursed throughout the codex emphasize Christian learning on social justice, the common good and social well-being, which norms emphasize the importance of man and family, as opposed to slave owners' norms in Byzantine legislation, ${ }^{9}$ and thus, in a Church-specific, evolutionary manner, pressure is exerted towards humanizing social relations, those based on subordinate work, through the concept of humanity, while at the same time ensuring that revolutionary reactions of subordinates are not incited so as to maintain social peace and stability. Namely, the Nomocanon protects wage labor, primarily their right to receive financial compensation for their work, thus it orders the regular payment of wages and forbids late payments to wage laborers. ${ }^{10}$ Additionally, forgiveness of debt is promoted in the spirit of humanity, as a social measure against the occurrence of debt slavery, primarily by limiting the period during which a debtor was required to work for a creditor on behalf of debt settlement, regardless of the debt amount, ${ }^{11}$ which social measure should be taken into account in light of the fact that in production relations, which gravitated during the creation of the Nomocanon, factual slavery was widespread and represented a social reality, even in developed medieval cities like Dubrovnik ${ }^{12}$.

It is also important to emphasize that the Nomocanon urges that, when interpreting regulations, priority be given to the spirit of the law over a formal expression of the norm, while at the same time emphasizing that while searching for meaning one should take into account the principle of humanity and the principle of special protection of the poor. ${ }^{13}$ In this manner, the writer of the codex is essentially advocating for a targeted method of interpreting regulations which is, even today, often an inexhaustible ideal. It provides additional guidance to institutions in the form of stressing humanity, and the special protection of the poor, as social ideals, which should be among the guiding ideals while searching for the

од другога: ни богаташ од сиромаха, ни господар од слуге, ни кнез од подвлашћеног, ни цар од војника, ни мудар од неуког - јер свима је даровао једну благородност,...“; М. Петровић, Љ. Штављанин Ђорђевић, 41.

${ }^{8}$ М. Петровић (1990б), 7-8.

${ }^{9} \mathrm{Ibid}, 4$.

10 „Да не преноћи плата твога надничара код тебе до јутра, нити пак да лишиш плате сиромаха..."; Ibid, 49.

11 „Ако је сиромашан брат твој код тебе и прода ти се, да не ради послове роба, већ као најамник или дошљак да буде код тебе до краја оне године када одлазе најамници или радници који раде код тебе, тада и њега отпусти и нека оде отпуштен....“; Ibid, 50.

12 Јелена Цвејић Даниловић, „О најамним односима у Дубровнику у XIII и XIV веку“, Анали Правног факулӣет̄а у Беогрраду 4/1961, 724-734.

13 „Да се нико не поводи за моћнима и богатима, већ сваки да узима у заштиту сиромашног кад му се суди“, „,..сиротима да се опрости осуда због неких погрешака“; $\mathrm{M}$. Петровић (1990б), 9-12. 
meaning of norms, thus influencing that the social relations that the Nomocanon regulates are significantly characterized by humanity and solidarity.

This regulation is along the line of a state structure founded, not only, on the principles of legal subordination, which is immanent to public law, and legal coordination, inherent to private law, but also on social integration, i.e., social ties, which principle is an essential feature of social security law and a contemporary social state. ${ }^{14}$ In this respect, it should be noted that the modern philosophy of building a European social model is founded on the values of solidarity and humanity, as well as the functioning of a production process while preserving social cohesion and social progress, i.e., the incomprehensibility of economic development without complete social progress which includes a greater degree of social inclusion and the strengthening of social cohesion. ${ }^{15}$

In a word, it can be concluded that the legal institutes of the Nomocanon that promote Christian learning on social justice are fundamentally the same as social justice ideals prevalent in the contemporary welfare state, within the domain of the European social model, i.e., that the subject institutes are the seeds of social justice in the Serbs. How well-founded and rooted these seeds were, or to what extent the writer had adjusted the legal norms to the spirit of the people, is best illustrated by the fact that the Nomocanon, as a code of regulations, was applied until the adoption of the Dushan's Code, and even after, thus it served as a source for Prota Matija Nenadovic and the first written law of the Serbian uprising. ${ }^{16}$

\section{SOCIAL RISKS AND SOCIAL CASES IN THE NOMOCANON}

The Nomocanon recognizes several social risks, namely: age, illness, incapacity for work, poverty and armed conflict, and answers these risks in an emancipated manner by introducing protective rules that protect persons in a state of social need, that is, persons for whom the danger of the occurrence of a harmful event, or state, has been transformed into reality by the emergence of a social case.

The risk of age is recognized by noting that this social risk, as a rule, involves the emergence of another social case. ${ }^{17}$ In this respect, the codex governs the risks of age, illness and incapacity for work with related protective provisions, which emphasize the obligation of respecting the dignity of persons suffering these social

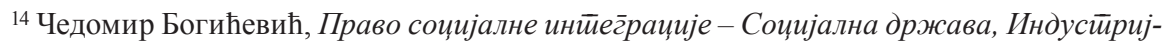
ска демокрайија, Слобода рада, Цетиње 2004, 13-22.

${ }^{15}$ Brian Bercusson, European Labour Law, Cambridge University Press, Cambridge 2009, 261-287; Д. Ђурић, Евройски сочијални модел, Београд 2013, 56-65.

${ }^{16}$ М. Петровић (1990б), 1-6; М. Петровић (1990а), 109-124.

17 „Старост не долази сама“; М. Петровић (1990б), 21.
} 
cases. ${ }^{18}$ In addition to emphasizing the importance of respecting the protection of dignity, the St. Sava's Nomocanon addresses protecting the material security of persons who are in a state of social need, and foresees legal institutes entrusted with the protection of the property of persons undergoing social events of age, illness and incompetence to work. ${ }^{19}$

With respect to the risk of poverty, the Nomocanon foresaw the existence of various honorable homes, which were, as a rule, monasteries and churches, or connected thereto, and which institutions essentially fulfilled a social care, i.e., social assistance, function. ${ }^{20}$ Namely, in these honorable homes there were national kitchens, living rooms, temporary accommodations and shelters, as well as hospital - medical services, financed mostly from bequeathed funds, ${ }^{21}$ which speaks greatly to the reputation these institutions enjoyed as well as a spirit of unity that prevailed in Serbian medieval society. The significance of these honorable homes, for the author of the Nomocanon, may be gleaned from a large number of protective norms, which protect these institutions from a reduction in property, inability for them to inherit the debts of the benefactors, making these institutions safer, but also preventive and repressive provisions aimed at preventing abuse by staff. 22

In addition to honorable homes, Nomocanon standardized the institution of church edicts, representatives of the poor, chosen by the more prominent locals headed by the bishop and the clergy, to which the bishop transferred his powers related to protecting the poor from the violence of the rich. ${ }^{23}$ It is also interesting to note that the poor could be excluded from testifying in order to prevent them from entering into greater difficulties related to testifying. ${ }^{24}$

Regarding the social risk of armed conflict, the codex primarily recognizes prisoners and wounded persons as individuals in a state of social need and, in addition to the obligation of the family to care for one of their own who has been captured or wounded, it instructs the entire community to care for them according to the principle of solidarity. ${ }^{25}$ Within this context, the Nomocanon stipulates that captivity is the only social case which permits the sale or encumbrance of church property.

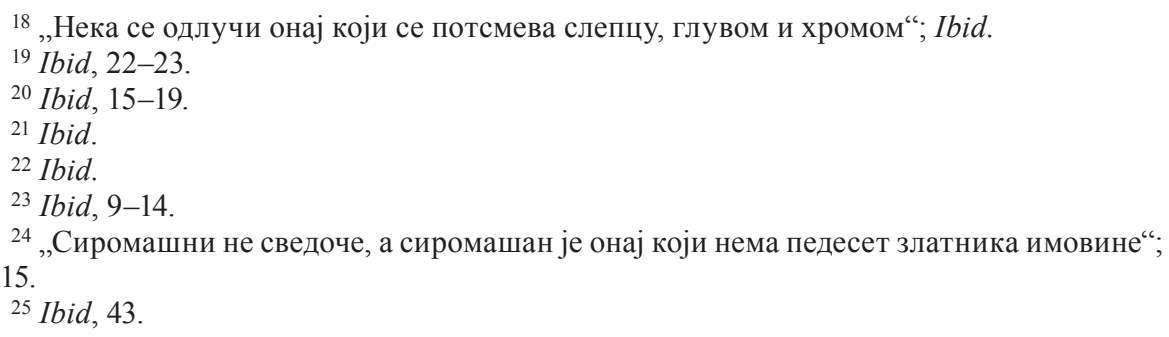




\section{SPECIAL PROTECTION OF WOMEN, CHILDREN AND FAMILY IN THE NOMOCANON}

In the spirit of Christian philosophy, the Nomocanon attaches great importance to the family, as an institution which initiates, develops and implements high social awareness. Namely, a considerable number of provisions taken from Byzantine regulations speak of the mutual social obligations of parents and children, ${ }^{26}$ while the significance attached to this social bond arises from the fact that parents and children are not allowed to leave one another uncared for, even under the excuse of piety and sacrifice. ${ }^{27}$ A parent who was preparing to take tonsure must first ensure social security for a child who is unable to care for himself, and vice versa, when an adult child was in charge of caring for a helpless parent, he must first secure the material resources for that parent and only after would he be permitted to bequeath the remaining property to the church. Therefore, the protection of the family, as the basic building block of society, was placed before the interest of the church, which is a significant element in light of the role and power of the church in medieval Serbia.

The St. Sava's Nomocanon recognizes a woman as the object of protection from the aspect of her maternal role, but it also recognizes her as a socially endangered category because of her uncertainty in marriage or in connection with marriage. ${ }^{28}$ Regarding maternity, a mother's special social awareness towards her child is emphasized, and specific rights are recognized, within this context, while in the domain of marriage, the woman's vulnerability, as a subordinate and economically weaker party in that legal relationship, is recognized, and certain protective standards are institutionalized. Thus, in the event of divorce, the husband is obliged to provide a dowry to the wife, so that she does not fall into social misfortunes, and such a dowry, as a claim, has priority for payment in relation to claims from other ordinary creditors as well as in relation to the debts of the husband towards the state. ${ }^{29}$ The codex also has special protective norms for widows and poor girls, ${ }^{30}$ where, in light of earlier Christian regulations, the Nomocanon recognized the state of the social need of widows and unmarried girls who did not

${ }^{26}, \ldots$. једно је старање наше тихости - благости, то је - да спречимо срамоту одбачених од наслеђа родитеља и деце, јер родитељи су дужни да се присете како су и сами били деца и исто то имали од својих родитеља, а слично томе и они који су сада синови, дужни су да исправе схватања родитеља, јер и сами желе да постану родитељи и надају се да ће од своје деце бити поштовани“; М. Петровић (1990б), 27.

${ }^{27}$ Ibid, 27-29.

28

${ }^{29} \mathrm{Ibid}, 37$.

30 „Не чините зло ниједној удовици и сиротама, а ако им нанесете зло те вапијући повичу к мени, чућу глас њихов и разгњевићу се јарошћу, и убићу вас мачем, и биће жене ваше удове и деца ваша сирота“; Ibid. 
enjoy the protection of parents, obliging the church with their care while at the same time imposing strict criminal and civil sanctions for violence against widows and virgins, freeing girls and women marked by violence from any spiritual guilt. ${ }^{31}$

From the above presentation of the selected norms of the codex, it follows that the subject provisions were the first steps towards the emancipation of our women and children, as particularly sensitive social categories, thus influencing a higher degree of ethical social relations, which moralization of social relations is one of the most important Church functions, in addition to the religious one. In connection with this, it can be noted that such a social role of the church overlaps with the function of social law, i.e., the role of social security institutions, to, while protecting persons in a state of social need, emancipate these individuals and groups and thus significantly affect the moralization of social relations.

\section{CONCLUSION}

According to the nature of things, the St. Sava's Nomocanon should be viewed as part of the Christian value system which is not only metaphysically oriented, in the sense of preaching faith, but contains a whole series of ethical requirements thereby contributing to the moralization of overall social relations, primarily through the concept of humanity. Additionally, Christianity also has a social domain which instructs in mutual help and solidarity, i.e., people's reliance on people and joint action for the common good and for mutual benefit. Within the social domain, the Nomocanon promotes Christian learning on social justice, founded on the idea of equality and solidarity, and a ban on oppression, as well as the principles of humanity and the special protection of the poor. Namely, it recognizes several social risks: age, illness, incapacity for work, poverty and armed conflict, and answers these risks with protective rules that protect persons in a state of social need, that is, persons for whom the danger of the occurrence of a harmful event, or state, has been transformed into reality by the emergence of a social case. In addition, the observed medieval codex contains norms that, in particular, protect women, children and families, which social categories are recognized as vulnerable. In a word, the Nomocanon is the first domestic source of law that contains emancipatory norms from the sphere of social relations bearing in mind that it is our first codex which promotes the idea of social justice, recognizes social risks and provides provisions that respond to the same risks, as well as provisions which protect the most vulnerable social categories, which corroborates the thesis that the St. Sava's Nomocanon is the beginning of social justice in the Serbs, since the essential feature of social law is the emancipatory character

${ }^{31}$ Ibid, 37-42. 
of provisions of that branch of law which pertain to persons and groups in a state of social need.

In keeping with all of the above, when the Nomocanon is placed in relation to social law in the modern welfare state, which law is founded on the principles of social security, solidarity and reciprocity, and the principles of humanism and social justice, all in order to ensure the safe and dignified position of man, and in particular within the framework of the European social model, which model insists on social inclusion and the strengthening of social cohesion, i.e., on the structure of the state not only on the principle of legal subordination, which is immanent to public law, and the principle of legal coordination, inherent in private law, but also on the order of social integration, i.e., social ties, as well as when taking into account that new social law recognizes age, illness, incapacity for work, poverty and armed conflict as a basic social risk, with the special protection of women, children and the family, it can be concluded that the legal institutes of the St. Sava's Nomocanon that promote Christian learning on social justice are basically the same as the idea of social justice of the modern welfare state, i.e., it follows that the subject institutes of the Nomocanon are, by their very nature, the same with the modern norms of the social security system, and that they really represent the beginnings, seeds, of social rights in the Serbs. 
Др Бојан В. Божовић, судија

Основни суд у Новом Саду

bojan.bozovic@ns.os.sud.rs

\section{Зачеци српског социјалног права у Законоправилу Светога Саве}

Сажейак: Радом се указује да, иако се слобода рада као йреййостиавка

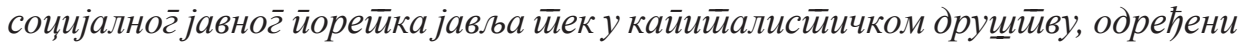

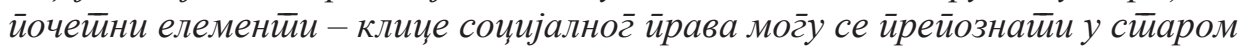
и средњем веку. У наведеном кониекксйу, иредмети истираживања јестие најобимнији срйски средњовековни кодекс, Законойравило Свейог̄а Саве, односно њег̄ове одредбе засноване на идеји соиијалне ирравде, норме усмерене на задовољење соиијалних ӣотиреба и одредбе којима се одг̄овара на соиијалне ризике и соиијалне случајеве, као и инстииичционализација йосебне зашиииие жена, деце и йородиче. Одайле се изводи закључак да йосмайране норме Свейосавског̄ номоканона које ирромовищу хрищћанско учење о соиијалној иравди и садрже низ етиччких захйева, кроз које уйичу на морализовање друшиивених односа, у основи јесу исте са идејом соиијалне иравде савремене државе благ̄осйања у оквирима евройског̄ соиијалног̄ модела, као и са еманщийайорском улогоом соиијалног̄ иррава, односно да су иии инстиийуйи Законойравила зачеции соиијалног̄ йрава у Срба.

Кључне речи: средњовековна Србија, Светии Сава, Законойравило, соичјално ирраво.

Датум пријема рада: 09.10.2018. 